\author{
Marek Serafin \\ Magister Prawa - Uniwersytet Warszawski \\ współzałożyciel i redaktor prowadzący portalu Polski Rynek \\ Transportu Lotniczego- PRTL.pl

\section{Ryszard Zaremba} \\ Magister inżynier - Budowa dróg i lotnisk - Politechnika Warszawska \\ Prezes Zarządu BSiPL \\ POLCONSULT Sp. z o.o.
}

DOI: 10.35117/A_ENG_19_08_02

\title{
Central Transportation Port (CPK) - Market Analysis
}

\begin{abstract}
The Project of Polish Central Transportation Port (CPK), which has already started, will be of the utmost importance for the whole Polish Transportation System. In addition, the cost of this investment is unprecedented. According to the current estimates the cost will surpass 100 billion Zlotys which means around 23.5 billion EUR. The success of CPK will depend on one condition that it becomes a great international hub. This is possible only if LOT Polish Airlines grows into one of the very few European and then global leaders in intercontinental air traffic. Such growth would, however, be against current strong and stable market trends. The most important is a consolidation trend. The effect of this trend is a growing market power of giants and marginalization or even bankruptcy of small and medium size airlines. Smaller carriers have good chances of survival - or even growth - if they find a stable market niche, which gives them protection from the competitors and market crises. In the process of consolidation an important role is played by Joint Venture Agreements. The parties to them suspend competition and behave in the markets as if they had the same owner. For the medium size network carriers the new and very dangerous market trend has already started. The low cost carriers are developing their intercontinental networks. According to the authors of the Project the great chances of market success of LOT Polish Airlines and CPK are created by the fact that in Central and Eastern Europe there is no dominating network carrier and this market is waiting for a leader. In our report we prove that according to the strong and reliable market data the Lufthansa Group is a dominant network carrier in CEE. To be successful LOT would have to take a large part of their market share. But even that will not be enough. LOT would have to dramatically increase its market share in Western Europe for transit traffic between Asia and Europe.
\end{abstract}

Keywords: Polish Central Transportation Port; Market analysis; Transit traffic

\section{Introduction}

In the history of Polish economy the project of Central Transportation Port is of unprecedented importance especially when we take into account the cost of this investment. The precise calculations are not ready yet but according to the official statements of Minister Wild the total amount can easily exceed 100 billion Zlotys. The current calculations show that the cost of the new airport and related infrastructure will reach 35 billion, the cost of new railways linking CPK with the most important Polish agglomerations -40 billion and the cost of building new agglomeration - Aerocity "living for and from CPK" - 25 billion. 
At the same time, it is almost certain that at least the biggest part of the financing of the project will have to be provided by the Polish State Budget, as it is very unlikely that the private finance institutions could be convinced to share the related financial risks.

We want to participate in the discussion concerning CPK as the presented justifications are surprisingly superficial and one-sided. They do not take into account many key factors that will influence the realization of the "big vision" and specific plans.

In this report we prove that the economical success of this investment necessary to repay the loans taken to finance it and to cover the very high operational cost generated by CPK will hinge on just one factor. We are convinced that it will be necessary that CPK becomes one of the leaders among the international transit airports, co called hubs, first on the European and then on the global stage. It will be possible only if LOT Polish Airlines advances to the group of world leaders competing mostly for the intercontinental transit traffic. It should be stressed that the current Polish airline is just a barely mid-size European Airline.

One of our most important criticism is that the decision makers ignore the trends of changes that dominate the air transportation market. It is necessary to establish how the European and global air markets will look like in more than ten years. We are convinced that they will be very different from the current one. In our opinion, the most important is and will be the consolidation trend resulting in the growing dominance of airline giants. At the same time the strategy on which the vision of CPK is based assumes that small in the global scale airline - LOT - will dramatically increase its market share of transit traffic at the expense of the current leaders. Such assumption does contradict the consolidation trend.

The most comprehensive justification for this investment is presented in the attachments to the Polish Council of Ministers' Resolution. In these documents we cannot find enough specific market-related elements. Among them two are of the greatest importance. The first argument assumes that in Central and Eastern Europe we experience the lack of a market leader which means that LOT Polish Airline has a great chance to achieve the dominant position. It would mean that CPK becomes a hub for this part of Europe. The second argument states that Warsaw is geographically very well located to compete for transit traffic. In our report we strive to prove that neither argument is based on the actual market situation.

The final decisions to start this gigantic investment have not yet been taken. The Feasibility Study has not been prepared and approved. Despite all of these, the administration, media and general public treat this matter as a done deal. In the near future, the fast-growing funds will be spent to prepare documentation for the project and then to break ground.

The vision of new CPK already has a great and direct influence on the strategy of the development of airport infrastructure serving the Warsaw agglomeration. In our opinion it is not a positive influence. Just the opposite. This vision is the main reason for freezing any development of Modlin airport and for planning the new investments in Radom Airport which are not based on market realities.

\section{Structure of the European airlines market and the position of LOT Polish Airlines}

In the next dozen years, CPK and CPL (Central Airport) together with LOT Polish Airlines are supposed to enter the European and global markets and successfully compete with the leaders. Before we describe the changes which will have a dominant effect on the air market in the end of the third and the beginning of the fourth decade of this century, it is necessary to describe the current structure of the market. It is the starting point for the outlook on the future. 


\section{European Market}

By far the strongest impact on the European air market comes from very big airlines operating according to two business models:

- Network (traditional). In this model the key role is played by transit airports - so called hubs. The big traffic systems are created and operated thanks to these hubs. For instance, the British Airways hub in Heathrow Airport enables BA to offer the transit trips between more than hundred cities in Europe and more than thirty cities in North America. The European market is already being dominated by three big groups of network carriers. Each of them has a common owner and is sharing the common strategy. These groups are:

i/Lufthansa Group: Lufthansa Airline, Swiss Airline, Austrian, SN Brussels and Eurowings,

ii/Air France/KLM Group: Air France, KLM Royal Dutch Airlines and Transavia, iii/IAG (International Airlines Group): British Airways, Iberia, Aer Lingus and Level.

It should be stressed that in case of Airlines Alliances of network carriers we can observe the commercial, operational and technical co-operation only, without any changes in the ownership structures.

- Low fare/low cost. These airlines do not create the transportation systems, but they concentrate on direct trips with the lowest possible prices. For instance, Ryanair operates from 86 bases located around Europe and in Northern Africa. Irish Ryanair and British easyJet are the biggest European Low Fare Airlines. In Central and Eastern Europe the important market role is played by Wizz Air. Norwegian, Eurowings, Transavia and Vueling should also be mentioned.

Tab. 1. traffic \& financial results in 2017 or financial year $2016 / 17$

$\begin{array}{ccccc}\text { Arline/ } & \text { Passengers } & \text { Revenue in mln. } & \text { Index to } & \text { Operational result/ } \\ \text { Group } & \text { in mln } & \text { EUR } & 2016 \% & \text { Comparable in mln }\end{array}$

\begin{tabular}{|c|c|c|c|c|c|}
\hline & & & & & to 2016 in $\mathrm{mln}$ \\
\hline $\begin{array}{c}\text { Group } \\
\text { Lufthansy }\end{array}$ & 130.0 & $28399)^{* *}$ & +15.2 & 2973 & +69.7 \\
\hline $\begin{array}{l}\text { Group } \\
\text { AF/KLM }\end{array}$ & 98.7 & 25781 & +3.8 & 1488 & +41.8 \\
\hline Group IAG & 104.8 & 22972 & +1.8 & 3015 & +18.9 \\
\hline $\begin{array}{l}\text { Turkish } \\
\text { Airlines }\end{array}$ & 68.6 & $\begin{array}{c}10958 \$^{*} \\
\text { ( } 9697 \text { EUR) }\end{array}$ & +11.9 & $\begin{array}{l}1022 \$^{*} \\
904 \text { EUR }\end{array}$ & $\begin{array}{c}+1313 \$^{*} \\
(1162 E U R)\end{array}$ \\
\hline SAS & 28.7 & 4426 & +8.1 & approx. 202 & +107.8 \\
\hline Finnair & 11.9 & 2568 & +10.9 & 170 & +209.0 \\
\hline Ryanair & 128.8 & 6648 & +1.7 & 1534 & +5.1 \\
\hline easyJet & 81.6 & 5047 & +8.1 & 461 & -21.8 \\
\hline Norwegian & 33.2 & 3316 & +19.3 & -214 & $-410 *$ \\
\hline WizzAir & 28.3 & 1948 & +24.0 & 275 (EBITDAR)*** & +22.1 \\
\hline
\end{tabular}

\section{LOT Polish Airlines situation}

Unfortunately we cannot show LOT's results in the same way as its competitors. This Polish company do not present "comparable results" obtained after eliminating one-time or 
extraordinary factors such as the changes in the aircraft financing, long and important operational irregularities and one-time financial transactions. Most airlines also provide their results without the influence of currency rates of exchange movements and changes in the fuel prices. Without such data we cannot compare LOT's results year by year and establish the trend of changes. The Polish carrier presents accounting results only, while the so called comparable results are of utmost importance to evaluate the financial situation of the airline.

From the LOT Board of Directors Report for the year 2017 we can learn that Polish Airline carried $6.8 \mathrm{mln}$ passengers. Its revenue reached the level of 4.8 billion Zlotys (around $1127 \mathrm{mln}$ EUR) and EBIT was $273 \mathrm{mln}$ - around 64mln EUR. We may not draw any long term strategic conclusions from the good financial results of LOT. They do not guarantee or even do not make it very probable that a similar situation may be repeated in the future. Especially, when we try to forecast LOT's results and financial position in 10-15 years.

\section{LOT chances for the great market success. Why it is very unlikely that Polish Airline can follow the Turkish Airlines path to success?}

The reasons for the above given premise could be divided into two groups. In the first group, the macro-economical factors are the most important. For many years we have been noticing very good general economical situation which created a growth in the demand for air services. The financial results of most of LOT's greatest competitors are much better, and the profitability of their operations is much higher. Relatively low level of fuel prices is also of great importance. This is even more important for LOT because in its cost structure the share of fuel cost is much greater than in case of other network carriers. Some elements of LOT's competitive level of unit cost are quite fragile, for example the controversial forms of employment of quite a big part of the manpower, especially employees with the highest salaries, such as pilots. It is very doubtful that this policy may be kept for many years. Polish Airline is also exposed to the deterioration of the market situation and to substantial increase in fuel prices. LOT does not have big financial reserves. Almost all their aircraft are in use under operational lease.

The second group of reasons, however, is much more important. CPK is supposed to be built for a completely different airline than current LOT. It is supposed to be built for a very big - even gigantic - network carrier which is able to gain a big part of its revenue in the very tough competition with the market sharks. CPK is in a very different situation from that of the new Istanbul airport built for Turkish Airlines. Turkish carrier will be continuing the current, well tested business model and the strategy that provided it with the great market and financial successes. THY many times proved that its resistance to crises situations is very high. It very well absorbed shocks coming from the global financial crises of 2008/2009 and from local political and military crises related to the Syrian domestic war.

\section{Dominant market processes}

The current structure of the network carriers market and the low fare airlines market is most of all the result of the consolidation process that had started several decades ago. Among the leading network carriers only Turkish Airlines do not belong to any Airlines group, and it must be stressed that this carrier is based outside the EU. Traffic carried by Turkish Airlines is similar to the traffic of three biggest EU Airlines (not Groups) - Lufthansa, Air France and British Airways. We will describe the unique market position of this airline and the specific reasons for its success in the next part of our report.

In the EU and in the whole of Europe, the dominant market positions are kept by three global groups with hubs providing them with global transit possibilities. As the result of a very fast development of low fare airlines offers on intra-European sectors, the network carriers had to focus on long haul markets. In Europe, new players have been more and more 
aggressive. The importance of intercontinental flights has been growing also because on shorter flights the share of business class tickets has been steadily decreasing. More and more business trips have been taken in economy class which means that the average yields have been decreasing and the profitability of substantial parts of the short haul markets of network carriers has become negative. After the global financial crisis, companies and corporations tried to economize on short business trips by limiting the number of Business Class tickets. On intercontinental flights the situation has been quite different. Banks and corporations are ready to pay high prices to provide their employees with the possibility of proper comfort during long trips.

For a few years after the global financial crises, the big airline groups had been focusing on achieving financial stability and on internal development. Later on, they became very active in the field of fusions and takeovers. Giants have decided that the time was right to speed up the consolidation processes. Global groups have also taken into account that despite the very good market situation, many mid-size carriers started to develop financial problems.

In the last five years the most important takeovers and fusions were done by two groups - Lufthansa Group and IAG Group. LH Group finalized the full takeover of SN Brussels Airline and absorbed a great part of bankrupt Air Berlin capacity. This Group has been also trying to take over failed Alitalia but was not successful as the Italian Government is still trying to create a "new big and independent Alitalia". Air Berlin and Alitalia were many times bigger airlines than LOT. IAG Group took over Irish Aer Lingus and started to develop a second transatlantic hub in Dublin supporting Heathrow. It was necessary since British Airways would have had only a very limited possibility to increase the number of flights and its capacity from the biggest London airport for many years. More than a year ago both Groups expressed their interest in taking over Norwegian - the first European low fare airline offering intercontinental flights with thirty wide body B787 aircraft. Just to compare: there are 12 B787s in LOT's long haul fleet and another three will come this year. IAG is very much interested in taking over Finnair and the only obstacle comes from the main shareholder - the Finnish Government. IAG together with Finnair Group could very actively enter the Europe - Asia market. Current IAG hubs (London, Amsterdam, Madrid and Dublin) are located in the Western part of Europe which limits Group possibility to a great degree to offer transit trips Europe - Asia. Europe - Asia market is already the biggest and the fastest growing intercontinental market. It means that the hub perfectly located in Northern Europe is of the utmost value for IAG.

We do not observe any consolidation type activity in case of AF/KLM Group. It even gave up the possibility to take over Alitalia despite the fact that it used to control $40 \%$ of Alitalia shares and a common strategy had been worked out. In this case the main obstacle is the lack of internal stability on the side of Air France. The Group is still commercially active thanks to a very well managed KLM and low fare airline Transavia.

We have noticed a new market phenomenon for more than a year. Low fare airlines have started to be active in the field of takeovers and fusions. easyJet was close to take over Air Berlin and for many months was trying, together with the group, to take control over Alitalia. Ryanair took over Laudamotion Airline which used to be called "the Austrian leftover" after a bankrupt Air Berlin.

Even this short overview is showing the strategy of European giants, how they see and understand the current situation and what kind of conclusions they draw from it. And for us the following finding is most important - the market space for smaller players is getting more and more limited and this process has not been finished yet. It will intensify. Giants started to be active also in the new field. Three big groups of network carriers have been developing the daughter companies - low fare airlines. They know that direct competition for the most price 
sensitive traffic with low fare airlines and especially with Ryanair is impossible. Like in many other cases the pioneer was Lufthansa. It has been developing a low fare airline - Eurowings many times faster than the network part of the group. Similar situation can be noticed in case of Transavia and AF/KLM Group. The Group in this case has special problems in France but it is quite possible that eventually the daughter company Transavia - France will be designated to compete in the Group's biggest market. Otherwise, the price sensitive market segment in France will be dominated by foreign giants and most by Ryanair.

\section{Long term Market Trends}

This part of our report will be devoted to the description of dominant and new market trends which we believe is very important.

Good recognition of the trends that dominate the market - or are just emerging - give the only chance to describe and most of all to understand the market of the future, the changes in its structure, the possibility to defend the current market position and to substantially improve it. Of course, we have to realize that we will see the great influence of non-economic factors since politicians will decide how fast the air transport markets will be opened on various continents. Even in Europe, BREXIT can cause unexpected turbulences but we hope that pragmatic approach will prevail. For the CPK project and for LOT Polish Airlines Europe, North America and Asia are the most important three continents. The first two are almost fully liberalized while the picture of the third continent is quite complex. The biggest and the most important question mark should be raised against China but as we can learn from the past international experience with the competitive abilities of Chinese companies growing fast, the eagerness of the Chinese government to open up a particular market segment grows fast as well.

\section{Consolidation Trend - ownership consolidation}

More than thirty years ago a visionary President of SAS - Jane Carlzon put a key task for his airline to be - "one of five in 1995". It does not really matter that reality was quite different. Jane Carlzon, the guru of the big airline bosses of that time, properly interpreted the trend when it was just emerging. Unfortunately, once again, the well-known saying: "nobody is a prophet in his own country" was proven right. JC very soon lost his job and SAS is now the biggest European network airline that does not belong to any global group.

Consolidation trend means that the number of participants playing key roles in the market game is getting smaller and smaller.

For network carriers - that is the most interesting airline model for us - this trend means:

- a new airline, together with its hub, joins the group, or

- by taking over the airline, the group improves the feeding systems of already functioning hubs.

We saw the examples of the first type of consolidation when Lufthansa took over Swiss (hub in Zurich) and Austrian (hub in Vienna). The second type of consolidation was when Lufthansa Group improved the feeding systems of its hubs by taking over SN Brussels. The Belgian carrier consequently focuses on delivering the transit traffic to four LH Group hubs. Zurich and Vienna are developed as hubs in the Group traffic system but this is not the case for Brussels. In professionally performed negotiations concerning changes in ownership, the status of the hub of the carrier being taken over is of the utmost importance.

\section{LOT in the process of the European consolidation}

According to some Polish media, consolidation means that a given airline expands its commercial activities to a new market any way they choose. For instance, the term 
"consolidation" was used when LOT established its new "mini-base" in Budapest or when it took control over the extremely small Estonian Airline - Nordica. But by making these moves, LOT has not entered the European consolidation game even to a minimal extent.

At the same time, those who criticize the extremely important role of the consolidation process in the area of network airlines market, usually point out the example of Turkish Airlines - an airline that advanced from a European "third league" to a small group of mega carriers. They do not understand that this example is unique and is not relevant when talking about position and strategic possibilities of LOT and Warsaw. A few points should be stressed here. The Turkish carrier took full advantage of some specific opportunities. First of all, Istanbul is perfectly located to enable passengers to take the shortest transit trips between large parts of Europe, (mostly the Southern and South-Eastern parts) and Asia/Africa. Big competing European hubs are located in the Western part of the continent. For the big part of the Middle East and Africa, Istanbul is the perfectly located hub for the trips to Asia and North America and v.v. Due to this geographical advantage, THY offers the highest number of international connections in the whole world. It was also important that the fast growth of Turkish Airlines was possible without the strict control of the EU. The Turkish carrier also took full advantage of its low salaries and low infrastructure costs.

\section{Consolidation and market position of hubs}

As earlier explained, the hubs play a key role in the consolidation process of network airlines market. Intercontinental trips with transit points are the most important field of competition between the airline giants. We have to stress that in the EU, there are only two mid-size hubs left - Helsinki and Lisbon - that are truly important and are used by two independent network airlines. Both fill in a niche, since the first specializes in the Asian traffic while the second in the South American traffic. It is possible to make round trips from Helsinki to most of the big and rich Asian agglomerations in a 24 hour aircraft rotation. It produces the most effective utilization of both aircraft and crew. Such flights can be operated to Tokyo, Osaka, Shanghai and even Bangkok while this rotation is not possible from Warsaw. The result is a very competitive unit cost for Finnair and an excellent product for its passengers - the shortest transit trip between most of Europe and key Asian markets.

Why do Finnair and Portuguese TAP stay outside the global groups? Finnair's Board of Directors would like to join one of the groups, most probably IAG, but the Finnish Government does not agree. The Portuguese Government has tried to join a global group through privatization but neither of the giants were interested. TAP's Alliance partner Lufthansa Group - would be the most probable investor but they declared their intent for the stable and long term commercial co-operation only. We can understand such a policy when looking at the geographical location of Lisbon, the closest European airport to South America and its biggest market - Brazil. TAP can offer transit trips between the whole of Europe and South America.

Both examples show how the professional managers see the future for their airlines. They understand that stable development and financial security could be guaranteed only by joining one of the global groups.

\section{Commercial consolidation - Joint Venture Agreements}

Commercial consolidation is a special type of market consolidation strengthening the overall consolidation trend. It happens when ownership consolidation is not possible for legal or political reasons. It is a global process and links giants from different continents. Quite a big part of our report is devoted to this topic, since it plays a very important role in the intercontinental markets. In addition, intercontinental Joint Ventures grow specifically on the 
North Atlantic and Europe - Asia markets, where Polish decision makers see the great growth potential for LOT and CPK.

In a Joint Venture Agreement, the group of independent airlines implements the legal and economical mechanism to fully suspend the competition between them and to bind their interests in a stable way. They start to act as if they had a common owner.

Joint Venture Agreements (JVA) with European Partners Commercial consolidation in Europe started first on the North Atlantic market. Today it covers a big part of that market. Three global European Groups concluded the JVA`s with giant American carriers:

- Lufthansa Group with United Group and Air Canada,

- AF/KLM Group (plus Alitalia) with Delta Group,

- IAG Group with American Airlines Group.

As a result, around $85 \%$ of the North Atlantic passenger traffic has been consolidated. In the first agreement which is the most interesting for us, joint commercial activities are performed not only in home markets of the partners but in the markets of whole continents, impacting Poland. A similar mechanism has most probably been implemented in the other two agreements.

The next market was the Europe - Asia market. Lufthansa Group first signed a JVA with the biggest Japanese carrier - ANA. As a result of this agreement, LOT, despite long efforts, could start only very limited commercial co-operation with ANA - LOT Alliance partner after inaugurating its flights to Tokyo. A few years later IAG concluded JVA with a smaller Japanese carrier - JAL.

The next step for the European carriers was to move into the opening Chinese market. After two years of negotiations, Lufthansa Group sealed JVA with Air China, the biggest international Chinese Airline. The AF/KLM Group signed an agreement with two partners China Eastern and Delta. At the same time, the shares of these three companies were swapped. Less than a year ago the chief of IAG informed that his Group started negotiations with the third big Chinese carrier - China Southern. The aim is the same - JVA.

It is not very likely that similar agreements will be signed with Korean Airlines. The reason is that the potential benefits would not be equal for both parties. The giant European Group would be able to contribute to the joint pool the big part of the European market while the Korean carrier could contribute its home Korean market only. In case of India the reason is different - the lack of a proper partner. Indian carriers have problems with image, operational reliability and level of service. When situation is improved, the three European Groups will become quite active.

\section{Effects of Joint Venture Agreements}

JVA dramatically changes the situation on markets. It suspends competition between the partners and implements the simple mechanism - "us against the rest of the world". Then the membership in the same alliance does not matter as illustrated by LOT's problems in Japan. As for China, it should be stressed that this market is fully controlled, specifically the foreign airlines capacity and slots at the Chinese airports. A JVA with a Chinese carrier provides almost full access to the local market - without one, an airline can experience constant problems and limitations.

In a JVA partners fully integrate their sales and marketing forces. For instance Lufthansa Group represents United Group and Air Canada in Europe and v.v. Partners conclude joint agreements with banks and corporations and their Frequent Flyer Programs closely co-operate.

These types of market agreement unique for airlines have enormous and often completely underestimated influence on the global balance of power. At the same time, they 
are quite controversial when we consider the need to keep the full competitiveness in the relevant markets. They limit or even freeze competition as the dominance of the giants is getting greater and the area of market activity for smaller players is being reduced. In the documents that substantiate the vision of CPK to become a global hub, the term "Joint Venture" does not appear. Also, there are no attempts to analyze the current competitive situation of the network carriers' market, the trends of its changes or the real chances of the smaller players to advance to leaders group.

\section{Low fare airlines on intercontinental market}

It is a common understanding that the fast development of low fare airlines offers on long haul market is certain. Unsure is just the rate of growth as we have to take into account also the non - market related factors, mainly global and regional political situation. The openness of EU market and introduction of Schengen area had a very positive effect on the development of low fare traffic in Europe.

\section{Technological changes and innovations}

When B747 was introduced, it was a common prediction that the era of four-engine, bigger and bigger super- giants able to carry enormous loads of cargo had started. With such big aircraft, the low fare airlines business model was not suitable for intercontinental connections since air cargo was not part of it and there was no chance to fill the giant aircraft with transit traffic. It was assumed that connections to very big hubs will dominate airline traffic. With this consideration, the giant A380 was introduced. Revolution in technology, introduction of bigger and more economical engines and composite aircraft bodies and wings meant that "giant" was no longer most economical. The first European intercontinental low fare airline entered the market when, after few years of delay, the newgeneration, two engine B787 Dreamliner was introduced. Later on a slightly bigger Airbus 350 started operations.

There are many reasons why low fare airlines offers will be developed on intercontinental markets quite fast. In our opinion, it is sufficient to take a look at the reaction of global European Groups. They do not want to repeat the mistake of ignoring the Ryanair and easyJet expansion. They do not underestimate the development of low fare airlines services on long haul markets. For these Groups the profitability of their intercontinental connection is of key importance. They have already established their own low fare intercontinental airlines and are developing their capacity really fast. Lufthansa uses their daughter company - Eurowings and IAG Group uses Level. In 2018 IAG and Lufthansa were interested in taking over the pioneer and the biggest European intercontinental low fare airline - Norwegian, which was in a difficult financial situation. It is unlikely, however, that the giants would compete only between themselves or within the groups. The fundamental question here is what the Ryanair plans are for the future? For many years the Ryanair CEO used to say that his airline would enter the long haul market but had to wait for the drop in B787 and A350 prices that should happen when the "first demand" for these aircraft has been met. It means that any responsible planner should take such a possibility into account. Even though we do not see further formal declarations and actions on the Ryanair Board of Directors side, this airline has already worked out or is working on their strategies necessary to perform such a revolution.

Expansion of low fare airlines on intercontinental markets has barely started but according to some analysts they have already captured almost $10 \%$ of the market share on the North Atlantic with a growing trend. New impetus will come from another technological breakthrough. In next few months narrow body A321 LR will enter services having just above 200 seats - depending on its configuration. The range of this aircraft will be $7400 \mathrm{~km}$. 
It means that the A321 LR can serve non- stop from big part of Europe to many cities in the USA and Canada located not only on the East Coast. The A321 LR will be a perfect aircraft to start low fare services between non-hub cities such as Barcelona/Dusseldorf/Oslo/Brussels and Boston/Montreal/Pittsburg/Philadelphia. It is possible that in the next few years Boeing will answer with a slightly bigger new narrowbody aircraft and before that, Airbus will create new commercial possibilities with the A321 XLR that should have even longer range than A321 LR. But even without these next steps, the A321 LR alone will enable airlines to offer ultra-low fares to millions of new passengers. And it is just a matter of time when ultra-long range narrow body aircraft will be used on some intercontinental services from Central Europe. It will be a serious competitive challenge for LOT.

\section{Intercontinental services}

When analyzing the effect of the growing share of low fare airlines on long haul markets, we should first of all take into consideration the following thesis. Inside the EU, the ultra-low fare and low fare airlines have taken over a limited number of short haul connections traffic from the traditional network carriers. They mostly created a completely new demand. We can easily prove it when we take the Polish market as an example. According to data published by the Polish Civil Aviation Administration (ULC) in the year 2004 (the year when Poland joined the EU and when the low fare airlines revolution started), the Warsaw Chopin Airport served slightly over $6 \mathrm{mln}$ passengers and all regional airports just $2.8 \mathrm{mln}$. With very few exceptions, only domestic flights were offered in these airports. By 2008 traffic to/from Warsaw grew by $55 \%$, thanks to a large extent to new services of low fare airlines. But a real breakthrough happened in regional airports where traffic grew four times mostly because low fare airlines, firstly Wizz Air and then Ryanair, started new international connections. This revolution was also possible due to close integration within the EU and Schengen areas and to stronger economic and cultural ties. On intercontinental markets the situation will be different and substantial part of the traffic carried by low fare airlines will be taken over from network carriers. For example, it will happen in case of traffic to/from South East Asia because tourists and Asians seeking employment in Europe are the dominant part of the market. On the North Atlantic tourist and ethnic traffic are very price sensitive. This will greatly restrict the market space of smaller, independent players. Right now their market share has dropped to less than $10 \%$ as the network carriers cooperating on the Joint Venture basis have the market share of almost $85 \%$ and the low fare airlines $-8.9 \%$. By "independent players" we mean first of all SAS, LOT, Icelandair and Finnair. These carriers will be the most vulnerable when the new competitive threat grows.

\section{Co-operation between the network carriers and low fare airlines}

For decades the low fare airlines have not shown any kind of interest in commercial cooperation with other carriers. They considered their prime task to offer the cheapest possible flight from point A to B.

In this context it was quite a big surprise when the CEO of Ryanair - Michael O'Leary declared that his airline was ready to negotiate and sign commercial agreements with the carriers who wished to drastically reduce the cost of transporting transit passengers to their long haul flights. Ryanair has been negotiating with the first intercontinental low fare airline - Norwegian and with another, Irish carrier - Aer Lingus which operates from its Dublin hub to more than a dozen cities in the USA and Canada. Dublin airport is the second biggest base of Ryanair. Negotiations have been prolonged as potential partners could not agree what rules should apply when passengers missed long haul flights because of delayed Ryanair flights. Many months ago they announced that an agreement was ready but we still 
do not know when and how it will be implemented. If and when it happens, Aer Lingus will strengthen its competitive position of in the struggle for transit traffic to and from Europe over the North Atlantic. Aer Lingus has suspended its Polish services, first to Cracow and later on to Warsaw. At the same time, Ryanair flies from Dublin to eleven Polish cities daily to Warsaw Modlin airport and to Cracow a few days a week, sometimes twice a day. If agreement becomes effective, the competitive situation to and from Poland over the North Atlantic will be changed substantially.

This new trend is in the very early stages of development. It is impossible yet to predict what its influence will be on the European intercontinental market but it could potentially be quite big. For network carriers the task to decrease the cost of connecting traffic transportation to and from their hubs has been one of the greatest challenges. Lufthansa's long haul network has been profitable for many years but its shorter flights have been unprofitable. The main reason was a very low level of average yield achieved from its short-haul transfer traffic.

Also, easyJet, the second biggest European low fare airline, intends to cut its share of this traffic as the carrier has signed a relevant agreement with Norwegian.

It is some kind of a paradox that the direction of this new trend on European long haul market will depend on the final decision of Ryanair whether to start its own intercontinental services. If the decision is positive, then its competitors operating according to network business model should not expect Ryanair to help them reduce the cost of transit operations. It is just a guess but Ryanair may have suddenly started to be interested in co-operation in transit intercontinental connections just to get direct experience in this market.

LOT should not expect that any low fare airline will help them reduce the cost of transportation of transit traffic to and from Warsaw. Such co-operation that produces quite substantial implementation cost on the low fare carrier side as well, makes sense only if the relevant connections of both partners in the base are very frequent. Transit connections must be automatically created without any changes in partners' schedules. Additionally, the chances of LOT's co-operation with low fare airlines have become minimal, also, because of the official policy of Chopin Airport management reducing access of LCC`s to the LOT hub. Also, in the long run, the CPK will not be tailored to them. We can say that the business profile of both airports almost completely exclude the possibility of any commercial cooperation between network carrier (LOT) and low fare airlines.

Currently big European network airlines do not use their low fare daughter companies to carry their connecting traffic. But in the long run, under a very strong competitive pressure, they may change their policy. Most probably they take into account the issue of image and possible strong opposition from the trade unions. But as we can see Emirates, the airline who cares very much for its image, has signed a code share agreement with its low fare daughter company - flydubai. It enables the airline to carry transit traffic to and from Cracow which is the flydubai but not Emirates destination. Similar arrangements apply on many other flydubai flights.

\section{Other chosen market trends}

Cargo traffic, growing importance of IT systems, network giants limiting commercial cooperation with smaller airlines, the marketing power of biggest airlines are some of the trends worth mentioning.

There is a growing importance of cargo traffic especially from and to Asia. This traffic requires the operation of giant logistic systems that provide the surface transportation within Europe and close partners on other side - Chinese and Japanese carriers. As an example, we can point out here that in 2018 Lufthansa Cargo Company had a revenue of 2.7 billion EURs 
and EBIT - 268 mln EURs. Both numbers are much bigger than the revenue and the operational profit of LOT.

Very big and costly IT systems are becoming more and more important for all airlines. One that plays a key role in the process of optimizing revenue of network airlines is a Revenue Management System. It helps carriers sell seats on each flight for an optimal set of prices from the cheapest to the most expensive.

Market giants reduce the scope of commercial co-operation with smaller airlines step by step. The attitude "us (the group) against the rest of the world" is more and more visible. This trend will get stronger when the market situation worsens and the competitive struggle for each passenger becomes tougher.

The marketing power of airline giants and groups may be used to create conglomerates selling air tickets and connected services. Ryanair employed more than a thousand experts and is building a platform that will offer "everything" - not only flights but also hotel rooms, car rental and even airport retail sales through the Internet. It will be a total offer for the big part of a non-business market. With this tool, Ryanair intends to dominate Internet sales of flights and related services.

The last two trends are just emerging but we have to take them into account because when we think about the current situation we are really seeing the market in more than a decade from now.

\section{LOT as a Regional Consolidator}

\section{Market realities in C\&EE}

The idea that LOT, as well as its hub - CPK, could become - thanks to consolidation of the market in our region - a very important player in Europe may be found in government documents as the most specific and essential substantiation of the CPK vision and project. Such a thesis has been repeated in all official statements of representatives of the Polish Government. Unfortunately it has many important, even fundamental weaknesses.

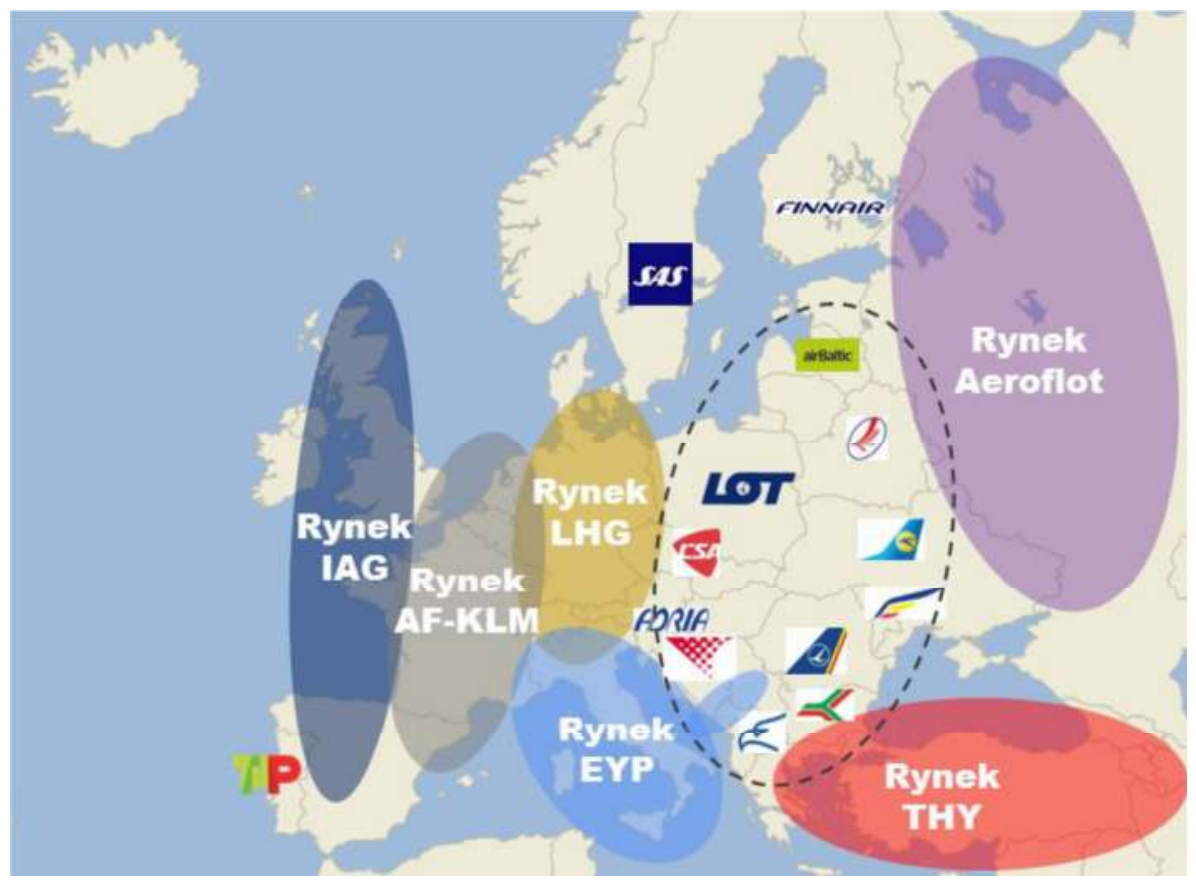

1. "Rynek" means "market" in the above map 
The map shown above included in Attachment Nr. 3 to the Resolution of the Polish Council of Ministers Nr. 173/2917 is supposed to illustrate the thesis that in C\&EE there is a lack of dominating carrier.

For the big part of our region (Southern and South-Eastern Europe) Vienna is geographically better located as a hub than Warsaw. Vienna is much closer to these countries and for flights to/from Western Europe passengers do not lengthen their trips as it happens when flying via Warsaw. The reasons justifying this statement may be found in the next part of our report. The most important thesis, however, is as follows: for the European Global Groups the entire Europe is a home market and the whole world becomes a home market directly or indirectly through their partners.

The official concept assumes that the market in our region is almost empty and "is waiting" for consolidation. In our dispute with the authors of market substantiations for the vision of the "Great CPK" it is beneficial to use the data that the authors included in the above mentioned Council of Ministers Resolution.

Udziały rynkowe na wybranych przepływach pasażerskich z regionu w 2016 r.
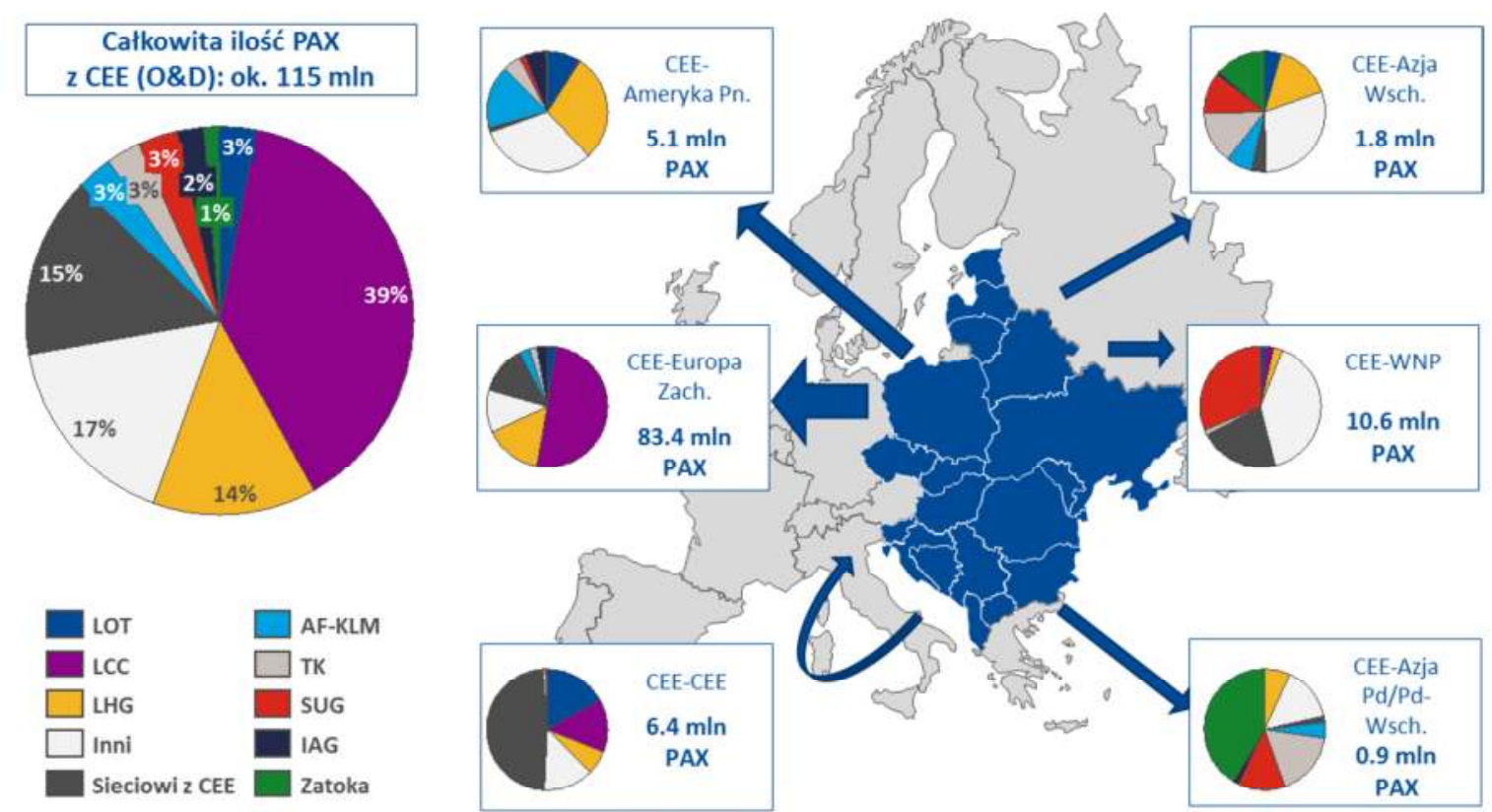

źródło: GDD

2. The passenger flights market in C\&EE

The map 2 presented above shows the market potential and market shares of the most important carriers on Origin - Destination basis (O\&D).

From maps Nr. $\mathbf{1}$ and $\mathbf{2}$ we can draw the conclusion that according to geographical criteria applied by the authors the Lufthansa Group does not have a hub located in our region even though its share in the total market $(115 \mathrm{mln}$ of passengers in 2016) amounts to $14 \%$ which means $16 \mathrm{mln}$ passengers. For comparison, LOT's share, with the hub in the region, was just 3\%. The Lufthansa Group actual share, however, is higher if we also take into account the J. V. passengers carried by the partners. If Austria and Austrian traffic were included, than the LH Group share would be increased to around 20\%, thanks to the direct traffic carried by the Group to and from Austria. In the C\&EE - Western Europe market (83,4mln passengers) which is by far the biggest, the position of the Group is especially strong. It carried almost $14 \mathrm{mln}$ passengers which means the market share is close to $16 \%$. The traffic of the second global group - AF/KLM was only $3.5 \mathrm{mln}$. A similar number of 
passengers was carried by LOT but it held the third position. An overwhelming majority of traffic carried by the Polish Airline was on direct flights, for instance from Warsaw to London, Paris and Brussels etc. . The Lufthansa Group, on the other hand, has been developing a huge intra-European transit traffic.

On the biggest intercontinental market - North Atlantic $(5.1 \mathrm{mln}$ passengers) the share of Lufthansa Group was around $28 \%$ (more than $1.4 \mathrm{mln}$ - carried on transit flights only). The passengers carried by LH Group J.V. partners (United and Air Canada) were not included in the chart and it is obviously a remarkable number. LOT traffic was a mere $0.6 \mathrm{mln}$ passengers despite the fact that it offers direct flights on this market.

Second biggest intercontinental market was East Asia (1.8mln passengers) and Lufthansa traffic was almost $0.3 \mathrm{mln}$. LOT started to develop its network in 2016 but even now its share is much smaller than that of the LH Group. Aeroflot airline is a much bigger competitor than LHG on this market - thanks to the geographical location of Moscow and a very competitive pricing policy for the price-sensitive part of the market.

The Europe - South \& South East Asia was the third biggest intercontinental market with relatively small share of the LHG traffic. The dominant positions were held here by the Gulf carriers, Turkish Airlines and Aeroflot. In this case, the geographic position of the hubs had a stronger influence together with the market characteristics - dominance of a very pricesensitive traffic in which LHG has had minimal interest. For LOT, chances to gain a high market share are slim because of the geographic location of Warsaw in the Northern part of our region. Chart 3 showing the capacity offered by LOT and LHG in the region of C\&EE (without Poland and Austria) and in the sub- regions in the Summer 2019 Season. The number of seats is expressed in thousands on any given group of connections. The source of data: data put into the reservation systems by airlines and downloaded by the Seabury APG Program.

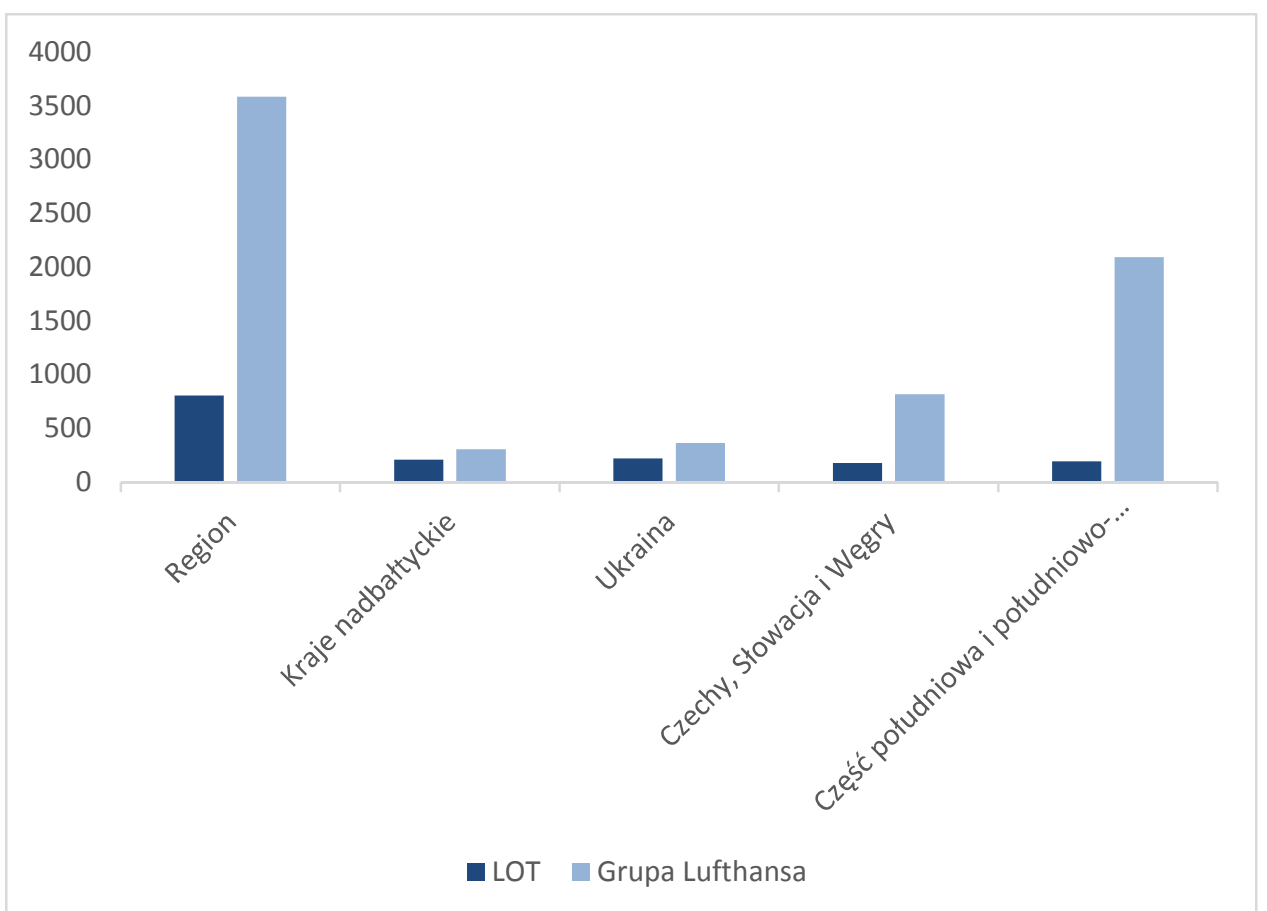

3. LOT and the Lufthansa Group in C\&EE (without Poland). Note: Number of seats offered, in thousands, on given call groups. Data source: timetable databases supplying systems booking. Seabury APG software 
The market shares reflect the importance of geography and illustrate that Warsaw is not well located in the C\&EE region. Only for the Baltic States Warsaw has a geographic competitive edge over LHG's hubs. On the Ukrainian market, Warsaw and Vienna are in equal position. In the rest of the region - the more we move to the South and South-East - the situation is getting worse for LOT. We also need to consider the extent of the LHG carriers` networks and their density that means the number of flights operated daily and weekly to different cities on almost all continents. As a result, the sales possibility of LHG in comparison to LOT are much higher. This factor plays the same role in the whole region.

\section{Situation in Polish Regional Airports}

Data regarding the number of seats offered by Lufthansa Group (without Eurowings) to Polish regional airports and by LOT on its domestic flights to Warsaw in the 2019 Summer Traffic Season show that LHG has a remarkable advantage over the Polish carrier even in Poland. LOT offers 1,445,500 seats while LHG - 1,727,000. This difference is getting smaller as LOT has increased its capacity by $8.7 \%$ in comparison to the Summer 2018 while LHG has not changed it. But the difference shown does not say everything. On LHG flights, $80 \%$ of the traffic is transit traffic to and from hubs. These are official LHG data. LOT does not publish precise numbers but historically transit traffic used to be around just $50 \%$. This percentage is most probably a little higher now. It is also worth mentioning that in the last more than ten years the competitive game for transit traffic in Polish regions has had just two players LOT and LH - who in the period between 2002 - 2008 were closely co-operating in codeshare arrangements. The current excellent situation in the Polish market attracts new airlines. KLM and recently Air France both started to offer new connections to the biggest and most important agglomerations in Poland. In a two way competition (LOT - LHG), the bigger and stronger player used to focus on high yield traffic leaving a relatively big market space to the smaller competitor. The price competition will be getting tougher, especially, if the market boom prevailing for the past few years weakens.

Other than in Poland, LOT has real chances to play an important market role only in two other sub-regions- the Baltic States and Ukraine. We need to remember, however, that LHG position is and will be much stronger since it offers gigantic networks from its four hubs and LOT could compete only on specific connections to destinations located on three continents, even though the number of these connections is growing.

\section{Conclusions}

Presented data prove that the C\&EE market is not a "desert" when we consider the offer of the strongest player in this part of Europe - Lufthansa Group, and LOT's position against this giant is simply too weak. In addition to the above, the geographic location of competing hubs - Warsaw, Vienna, Munich and Frankfurt is extremely important.

\section{Source materials}

[1] https://www.gov.pl/documents/905843/1047987/koncepcja_przygotowania_CPK.pdf/ f61866f9-4ea9-b5d7-cfd7-fdfaa563b876 [access 27.03.2019]

[2] Attachment 1 to the Resolution of the Council of Ministers on CPK - Potencjat Konsolidacji Rynków Europy Środkowo - Wschodniej przez PLL LOT" and subtitle of the second part - „Niezagospodarowany Potencjał Rynku”

[3] The Resolution Nr 173/2017 of the Council of Ministers, dated 7.11.2017 „W sprawie przyjęcia koncepcji przygotowania i realizacji inwestycji Port Solidarność - Centralny Port Komunikacyjny dla Rzeczpospolitej Polskiej" - Attachment 1 page 96. 